\title{
Pengembangan Preventive E-Education Berbasis Aplikasi Play Store untuk Membatasi Dependensi pada Asupan Gula, Garam, dan Lemak
}

\author{
Rr. Siti Alisa Nur Zubaidah \\ Kepala Tenaga Administrasi Sekolah, Sekolah Dasar Negeri Kesatrian 2 Malang, Indonesia
}

\begin{abstract}
Abstrak
Tujuan penelitian ini adalah mengembangkan preventive e-education berbasis aplikasi Play Store yang layak, praktis, dan efektif untuk membatasi dependensi pada asupan gula, garam, dan lemak. Penelitian pengembangan ini menggunakan model ADDIE dengan 4 tahapan yang terdiri dari: (1) Tahap analyze, (2) Tahap design, (3) Tahap development, (4) Tahap implementation. Tahap evaluate tidak dilakukan oleh peneliti karena keterbatasan waktu. Validasi produk oleh ahli materi, bahasa, ahli media. Uji coba produk mengukur respon kepala sekolah dan 50 guru di SD negeri dan swasta se-gugus 4 Kecamatan Blimbing Kota Malang. Instrumen observasi, lembar angket, dan dokumentasi. Berdasarkan hasil validasi pada ahli materi memperoleh nilai rata-rata $85,7 \%$, ahli media memperoleh nilai rata rata $93,5 \%$, ahli bahasa memperoleh nilai 91\%. Hasil angket oleh guru memperoleh $87,6 \%$. Uji coba terbatas pada guru kelas $\mathrm{V}$ memperoleh 95\%. Dengan demikian, preventive eeducation berbasis aplikasi Play Store layak, praktis, dan efektif digunakan sebagai edukasi preventif untuk membatasi dependepnsi pada asupan gula, garam, dan lemak kepala sekolah dan guru di Sekolah Dasar Negeri dan Swasta se-gugus 4 Kecamatan Blimbing Kota Malang.
\end{abstract}

Kata Kunci:

Preventive, E-

Education, Aplikasi

Play Store

\begin{abstract}
The purpose of this study is to develop preventive e-education based on Play Store applications that are feasible, practical, and effective to limit dependencies on sugar, salt, and fat intake. This development research uses ADDIE model with 4 stages consisting of: (1) Analyze Phase, (2) Design stage, (3) Development stage, (4) Implementation phase. Due to time constraints, the evaluate stage was not conducted by the researcher. Product validation by material experts, languages, media experts. The product trial measured the responses of school principals and 50 teachers in public and private elementary schools in Group 4 of Blimbing District, Malang. Observation instruments, questionnaire sheets, and documentation. Based on the results of the validation on the material experts obtained an average value of $85.7 \%$, media experts obtained an average value of $93.5 \%$, linguists obtained a value of $91 \%$. The results of the questionnaire by the teacher gained $87.6 \%$. Trials limited to class $\mathrm{V}$ teachers gained $95 \%$. Thus, preventive e-education based on Play Store application is feasible, practical, and effective to be used as preventive education to limit dependence on sugar, salt, and fat intake of school principals and teachers in public and private elementary schools in group 4 Blimbing District Malang.
\end{abstract}

\section{Keywords:}

Preventive, E-Education, Play Store Application 


\section{PENDAHULUAN}

Asupan makanan merupakan faktor penting yang dapat memengaruhi status gizi. Hal tersebut dikarenakan kuantitas dan kualitas makanan dan minuman yang dikonsumsi dapat memengaruhi tingkat kesehatan individu dan masyarakat. Status gizi yang baik dan seimbang dapat membuat berat badan sehat dan normal, tubuh tidak mudah terserang penyakit infeksi, produktivitas kerja semakin meningkat serta terhindar dari penyakit kronis dan kematian dini. Sedangkan gizi yang tidak baik dapat menimbulkan kesehatan tubuh yang buruk dan berdampak pada risiko menjangkitnya penyakit degeneratif seperti penyakit jantung, pembuluh darah, hipertensi, stroke, dan diabetes mellitus serta kanker yang merupakan penyebab utama kematian di Indonesia.

Menurut (Kistianita, dkk, 2015), data laporan bulan Puskesmas Kendalkerep Kota Malang penderita penyakit Diabetes Mellitus mengalami peningkatan yang cukup signifikan. Terbukti pada tahun 2013 jumlah kunjungan penderita penyakit Diabetes Mellitus yang melakukan pemeriksaan sebanyak 3561 orang dan pada tahun 2014 meningkat menjadi 3896 orang. Hasil laporan bulan tersebut menunjukkan bahwa penderita Diabetes Mellitus paling banyak terjadi pada usia anak-anak dan remaja. Hal ini disebabkan oleh pola hidup anak-anak Indonesia khususnya di kota Malang sekarang yang tergiyur oleh tersedianya berbagai makanan siap saji dan siap olah, kebiasaan ngemil, dan kurangnya informasi serta edukasi tentang gizi yang menyebabkan masyarakat khususnya anak-anak usia sekolah dasar dihadapkan pada pola makan atau konsumsi makanan sehari-hari yang tidak seimbang. Sebagian besar masyarakat pada umumnya berasosiasi dengan kelebihan gizi, kelebihan gizi ini timbul akibat kelebihan asupan makanan dan minuman yang mengandung gula, garam dan lemak atau minyak berlebih.

Gula, garam, dan lemak atau dapat disingkat GGL merupakan gizi yang mengandung sumber energi yang positif bagi tubuh jika dikosumsi dengan baik. Berdasarkan Riset Kesehatan Dasar pada tahun 2013, masyarakat Indonesia khususnya anak-anak usia sekolah dasar yang mengkonsumsi gula berlebih sebanyak 53,1\%, anak-anak yang mengkonsumsi garam berlebih sebanyak 26,2\% dan sebanyak 40,7\% mengkonsumsi lemak berlebih. Akibat yang paling fatal dari konsumsi gula, garam dan lemak berlebih adalah menyebabkan penumpukan radikal bebas pada tubuh. Radikal bebas itulah yang dapat mengakibatkan kerusakan pada Deoxyribo Nucleic Acid (DNA) dan mutasi gen serta pertumbuhan dan perkembangan sel secara tidak wajar, sehingga muncul penyakit degeneratif seperti stroke, kanker, dan diabetes mellitus. (Anwari, 2018)

Pentingnya kegiatan Usaha Kesehatan Sekolah (UKS) di sekolah dasar diarahkan untuk mengatur kadar gula, garam, dan lemak melalui upaya pendidikan dan kesehatan yang dilaksanakan untuk mendukung program pedoman gizi seimbang bagi kesehatan masyarakat sekolah. UKS di sekolah penting dalam mendukung fakta terkait kelompok usia sekolah di Indonesia yang merupakan kelompok usia yang paling besar populasinya. Besarnya jumlah populasi kelompok umur anak sekolah ini, tentu berisiko terhadap kontribusi permasalahan kesehatan masyarakat. Tantangan yang paling sering dihadapi oleh sekolah dalam melakukan pembinaan dan pengembangan UKS adalah keterbatasan media edukasi UKS yang ada di sekolah, khususnya tingkat Sekolah Dasar. Selain itu, permasalahan yang sering muncul adalah kurang optimalnya peran sosialisasi UKS di tingkat Sekolah Dasar dalam rangka meningkatkan presentase kesehatan masyarakat sekolah.(Amir, dkk, 2018)

Perkembangan teknologi di era revolusi industri 4.0 memberikan dampak terhadap edukasi berbasis teknologi. Teknologi termasuk salah satu aspek penting dalam memperoleh dan mengembangkan ilmu pengetahuan saat ini. Salah satu komponen pendidikan kesehatan yang sudah memanfaatkan teknologi adalah edukasi preventif. Edukasi preventif yang menguntungkan masyarakat yaitu edukasi yang menggunakan teknologi dalam mengakses informasi sesuai keperluan masyarakat. (Sugiana, dkk. 2016)

Berdasarkan analisis kebutuhan di lapangan kelebihan tingkat konsumsi gula, garam dan lemak masyarakat di Indonesia semakin meningkat setiap tahunnya. Kementerian Kesehatan Indonesia menganjurkan pembatasan konsumsi gula per orang seharinya adalah 50 gram (4 sendok makan), batasan garam per orang seharinya adalah 5 gram (1 sendok teh) dan batasan konsumsi lemak atau minyak per orang seharinya adalah 67 gram ( 5 sendok makan). Hal ini telah ditetapkan pada program Pedoman Gizi Seimbang (Arizal dkk, 2018). Namun, program tersebut kurang tersosialisasikan secara luas kepada masyarakat khususnya pada anak-anak di sekolah dasar. Hal ini sesuai dengan data kuesioner bahwa 71,62\% para guru dan anak-anak sekolah dasar di Kota Malang belum mengetahui batasan konsumsi gula, garam dan lemak perharinya.

Dengan memperhatikan permasalahan tersebut, maka diperlukan suatu edukasi preventif berbasis aplikasi play store khususnya pada kepala sekolah, guru dan tenaga kependidikan melalui program UKS di SD Negeri dan Swasta se-Gugus IV Kecamatan Blimbing Kota Malang. Hal tersebut diperlukan agar para kepala sekolah, guru dan tenaga kepedndidikan dapat mengakses informasi tentang 
pedoman gizi seimbang dan informasi tentang edukasi preventif untuk membatasi dependensi pada asupan gula, garam, dan lemak serta menyebarluaskan akses infomasi yang diperoleh kepada masyarakat sekitaranya terlebih kepada wali murid siswa sekolah dasar nantinya. Program tersebut penting untuk menunjang kesehatan peserta didik di suatu lembaga pendidikan. Untuk mendukung terciptanya peserta didik yang sehat dimulai dari kepala sekolah, guru, dan tenaga kependidikan yang sehat. Sekolah dapat merealisasikan dengan mengaktifkan edukasi preventif berbasis aplikasi play store melalui program usaha kesehatan sekolah yang bertujuan untuk meningkatkan kesehatan yang optimal sehingga dapat memaksimalkan potensi dan prestasi anak untuk belajar. Dengan adanya edukasi preventif berbasis aplikasi play store, maka akan meningkatkan pemahaman masyarakat tentang pedoman gizi seimbang dan agar terhindar dari berbagai penyakit degeneratif seperti diabetes mellitus.

Teknologi yang berpotensi untuk membantu tercapainya tujuan edukasi preventif untuk membatasi dependensi pada asupan gula, garam, dan lemak adalah Preventive E-Education berbasis aplikasi Play Store. Preventive E-Education berbasis aplikasi Play Store dapat memberikan informasi penting secara luas tentang Pedoman Gizi Seimbang dan mencegah ketergantungan pada asupan gula, garam, dan lemak. Kesalahan yang bersumber pada masyarakat yang melakukan sosialisasi sering dipengaruhi oleh subyektifitas dan kesalahan informasi terkait edukasi asupan gula, garam, dan lemak berlebih. Hal ini dapat diperbaiki dengan suatu Preventive E-Education (Preventive Electronic Education) yang terintegrasi dengan aplikasi yang secara otomatis dapat memberikan informasi secara live streaming, akurat dan akuntabel untuk menghindari berbagai penyakit degeneratif yang disebabkan oleh dependensi atau ketergantungan pada asupan gula, garam, dan lemak berlebih.

Penelitian tentang pengembangan edukasi yang pernah dilakukan oleh Hidayah, dkk (2019) menunjukkan bahwa edukasi yang dikembangkan efektif digunakan karena dapat membantu masyarakat dalam memahami materi dan menambah pengetahuan tentang kesehatan. Tetapi pada penelitian tersebut hanya berisi materi-materi seputar kesehatan saja tidak ada challenge, quiz dan reward pada aplikasi tersebut, sedangkan edukasi yang dibutuhkan pada era digital dan abad 21 saat ini menuntut sistem edukasi elektronik berbasis aplikasi play store yang dapat diakses oleh masyarakat baik secara online maupun secara offline. Berdasarkan perbedaan edukasi berbasis komputer pada penelitian terdahulu dan kebutuhan saat ini, maka Preventive E-Education berbasis aplikasi Play Store penting untuk diteliti dan dikembangkan.

Preventive E-Education berbasis aplikasi Play Store yang akan diteliti dalam penelitian ini berbeda dengan penelitian sebelumnya. Preventive E-Education ini mencakup berbagai modul terintegrasi dan bersifat multiuser sehingga dapat diakses oleh kepala sekolah, guru, dan tenaga kependidikan, dan orangtua. Edukasi elektronik preventif ini memberikan informasi dalam bentuk platform android dan berbasis web serta memiliki 4 fitur unggulan antara lain: (1) Announcement (pengumuman). Fitur ini berisi material and information (materi dan informasi) yang memberikan informasi penting secara luas, akurat, akuntabel, dan selalu update terkait pedoman gizi seimbang dan strategi preventif untuk membatasi dependensi atau ketergantungan pada asupan gula, garam, dan lemak. Pada menu ini juga berisi informasi yang dapat dilihat secara live streaming atau siaran langsung yang terupdate tentang pembatasan asupan gula, garam, dan lemak untuk menghindari berbagai penyakit degeneratif seperti diabetes mellitus; (2) Challenge (tantangan). Fitur challenge ini berisi kegiatan yang harus dilakukan untuk mengukur kemampuan dalam membatasi ketergantungan pada asupan gula, garam, dan lemak; (3) fitur quiz and reward (kuis dan penghargaan). Fitur Quiz digunakan untuk mengukur tingkat pemahaman terkait materi yang telah dipelajari pada fitur announcement. Menu reward ini digunakan untuk memberikan poin kepada pengguna aplikasi setelah melakukan quiz; dan (4) chat (obrolan). Fitur chat merupakan fitur yang dapat digunakan untuk berkomunikasi dengan kepala sekolah, guru, dan tenaga kependidikan dengan efektif, hemat, dan cepat.

Preventive E-Education ini dapat diakses oleh masyarakat di sekolah pada umumnya melalui android baik secara online maupun offline. Namun, masyarakat di sekolah yang akan mengakses aplikasi tersebut harus memiliki user atau akun terlebih dahulu. Akun tersebut dapat dibuat melalui sistem android pada masing-masing handphone dengan mengikuti petunjuk pengguna yang terdapat di aplikasi tersebut. Preventive E-Education berbasis aplikasi Play Store ini fokus untuk membatasi dependensi pada asupan gula, garam, dan lemak untuk mencegah penyakit degeneratif seperti Diabetes Mellitus khususnya pada anak-anak usia sekolah dasar. 


\section{METODE PENELITIAN}

Penelitian pengembangan Preventive E-Education berbasis aplikasi Play Store ini dilaksanakan dengan menggunakan model penelitian Research and Development (R\&D) model ADDIE. (Masturah, 2018) mengemukakan bahwa tahapan-tahapan siklus R\&D model ADDIE yaitu, Analysis, Design, Development, Implementation dan Evaluation.

Analysis kepala sekolah, guru, dan tenaga kependidikan SD Negeri dan Swasta se-gugus IV Kecamatan Blimbing membutuhkan edukasi preventif yang lebih inovatif, media edukasi berbasis teknologi atau komputer, dan program didesain secara tepat dan menarik dengan memberikan gambar dan animasi, challenge, quiz dan reward. Agar kepala sekolah, guru, dan tenaga kependidikan SD Negeri dan Swasta se-gugus IV Kecamatan Blimbing mendapat pengalaman edukasi yang baru, agar proses edukasi preventif dalam upaya membatasi dependensi pada asupan gula, garam, dan lemak akan lebih menarik dan informasi edukasi preventif dapat tersampaikan secara luas kepada masyarakat dan dapat lebih mudah memahami edukasi preventif secara online maupun offline yang berlangsung perlu menggunakan alat atau media pembelajaran (Ayu, 2009). Design tahap perencanaan yaitu berisi pembuatan flow chart dalam perancangan pembuatan edukasi preventif yang dibutuhkan masyarakat pada umumnya untuk membatasi dependensi pada asupan gula, garam, dan lemak dengan menggunakan Preventive E-Education berbasis aplikasi Play Store. Gambar di sajikan pada Gambar 1. Flowchart.

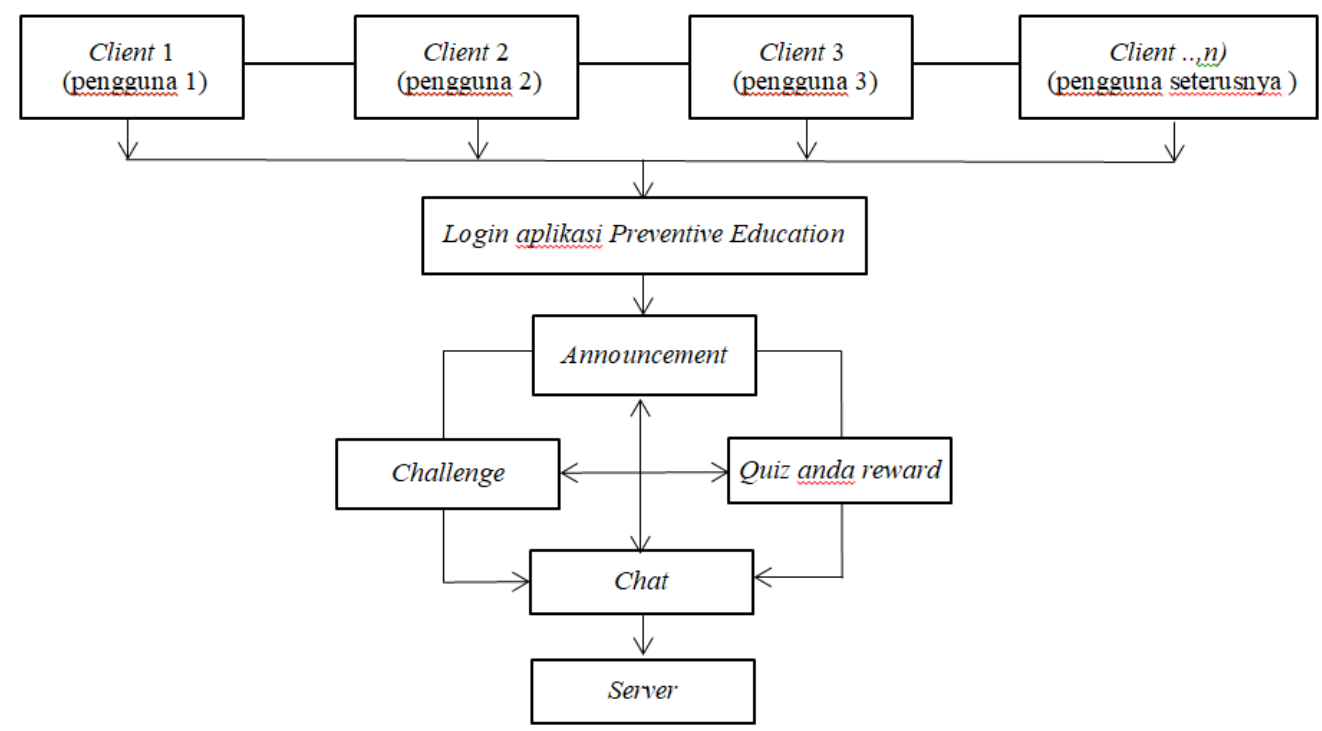

Gambar 1. Flowchart

Pada tahap development, peneliti membuat produk berdasarkan desain atau rancangan yang telah dibuat. Setelah produk selesai dibuat, peneliti melakukan validasi kepada tiga ahli yaitu: ahli media, ahli materi, dan ahli bahasa. Validasi yang dilakukan peneliti mendapatkan hasil rata-rata persentase 88,03\% dari hasil rata-rata tersebut peneliti melakukan revisi media lagi sehingga media pembelajaran dapat dikatakan layak untuk di uji cobakan. Implementation, pada tahap ini Preventive E-Education berbasis aplikasi Play Store diimplementasikan pada uji coba lapangan terbatas pada 50 guru kelas di SD negeri dan swastas se-gugus 4 Kecamatan Blimbing Kota Malang. Pada tahap implementasi ini dilakukan untuk mendapatkan data yang dibutuhkan untuk menguji kelayakan Preventive E-Education berbasis aplikasi Play Store.

Pada tahap implementasi kepala sekolah, guru, dan tenaga kependidikan dapat mengoperasikan edukasi preventif dengan baik dan guru juga dapat dengan mudah memahami materi edukasi, sebab guru jarang sekali mendapat edukasi preventif berbasis aplikasi play store sehingga guru dapat termotivasi untuk mengikuti proses challenge dan quiz. Evaluation, tahap evaluasi untuk memperbaiki media yang telah di revisi oleh ahli media dan diterapkan untuk pembelajaran. Pada tahap evaluasi tidak dilakukan oleh peneliti karena keterbatasan waktu.

Penelitian dan pengembangan ini menghasilkan produk Preventive E-Education berbasis aplikasi Play Store untuk membatasi dependensi pada asupan gula, garam, dan lemak. 


\section{ANALISIS DAN PEMBAHASAN}

Hasil pengujian produk membahas tentang validasi Preventive E-Education berbasis aplikasi Play Store melalui instrumen kelayakan. Instrumen kelayakan ini diberikan kepada ahli media, ahli bahasa dan ahli materi.

Validator memberikan penilaian, komentar dan saran pada lembar validasi yang disusun berdasarkan data yang dibutuhkan oleh peneliti untuk pengembangan produk. Hasil dari penilaian masing-masing validator digunakan sebagai acuan dalam perbaikan media yang dikembangkan. Hasil dari penilaian masing-masing validator dipaparkan sebagai berikut.

Tabel 1. Hasil Kelayakan Preventive E-Education Berbasis Aplikasi Play Store

\begin{tabular}{cc}
\hline Keterangan & Presentase \\
\hline Ahli Materi & $85,7 \%$ \\
Ahli Media & $93,5 \%$ \\
Ahli Bahasa & $91 \%$ \\
\hline
\end{tabular}

Validasi media Preventive E-Education berbasis aplikasi Play Store dari ahli media bertujuan untuk mengetahui kelayakan dan pendapat serta saran dari ahli yang berpengalaman di bidang media pembelajaran. Penilaian media Preventive E-Education berbasis aplikasi Play Store terdapat beberapa aspek di antaranya kelayakan ukuran gambar animasi, kelayakan desain display animasi, dan kelayakan desain animasi.

Diketahui bahwa media Preventive E-Education berbasis aplikasi Play Store rata-rata dari keseluruhan aspek mendapat 93,5\%. Lembar validasi yang digunakan menggunakan rating scale dengan kriteria penilaian diantaranya:

Tabel 2. Rating Scale

\begin{tabular}{ccc}
\hline No. & Pilihan jawaban & Nilai skala \\
\hline 1. & Sangat tidak baik & 1 \\
2. & Tidak baik & 2 \\
3. & Baik & 3 \\
4. & Sangat baik & 4 \\
\hline
\end{tabular}

(Sugiyono,2009:135)

Validasi ahli materi Preventive E-Education berbasis aplikasi Play Store dari ahli materi bertujuan untuk mengetahui kelayakan dan pendapat serta saran dari ahli yang berpengalaman di bidang materi pembelajaran. Penilaian Preventive E-Education berbasis aplikasi Play Store mencangkup beberapa aspek di antaranya kelayakan isi, kelayakan penyajian, kelayakan keterlaksanaan dan kelayakan evaluasi. Berdasarkan penilaian yang diperoleh dari ahli materi.

Diketahui bahwa materi pada Preventive E-Education berbasis aplikasi Play Store mendapat persentase keseluruhan aspek nilai 85,7\%, dengan kategori "sangat layak" di dukung dengan penelitian yang berjudul "Pengembangan Media Evaluasi Belajar IPA Berbasis Web Offline (Pada Pokok Bahasan Makhluk Hidup dan Proses Kehidupan) Berdasarkan SKL 2013 di Madrasah Ibtidaiyah Imami Kepanjen Malang" memperoleh skor 86,6\%, media termasuk kategori baik, dan media layak untuk diujicoba tan pa revisi. Lembar validasi yang digunakan menggunakan rating scale.

Validasi ahli bahasa Preventive E-Education berbasis aplikasi Play Store dari ahli bahasa bertujuan untuk mengetahui kelayakan dan pendapat serta saran dari ahli yang berpengalaman di bidang bahasa. Penilaian Preventive E-Education berbasis aplikasi Play Store mencakup beberapa aspek di antaranya kelayakan isi, kelayakan penyajian, kelayakan keterlaksanaan dan kelayakan evaluasi. Berdasarkan penilaian yang diperoleh dari ahli bahasa 91\%.

Diketahui bahwa bahasa pada Preventive E-Education berbasis aplikasi Play Store mendapat persentase keseluruhan aspek mendapat nilai 91\%, dengan kategori "sangat layak" di dukung dengan penelitian yang berjudul "Pengembangan Media Evaluasi Belajar IPA Berbasis Web Offline (Pada Pokok Bahasan Makhluk Hidup dan Proses Kehidupan) Berdasarkan SKL 2013 di Madrasah Ibtidaiyah Imami Kepanjen Malang" memperoleh skor 86,6\%, media termasuk kategori baik, dan media layak untuk diujicoba tanpa revisi. Lembar validasi yang digunakan menggunakan rating scale.

Hasil validasi untuk pengukuran kepraktisan juga di lakukan oleh kepala sekolah dan guru menggunakan menggunakan angket. Hasil aspek disajikan pada Tabel 3. berikut. 
Tabel 3. Penilaian Respon Kepala Sekolah, Guru, dan Tenaga Kependidikan

\begin{tabular}{lc}
\hline \multicolumn{1}{c}{ Aspek yang dinilai } & Presentase \\
\hline Kepraktisan kepala sekolah & $94,8 \%$ \\
Kepraktisan guru & $87,6 \%$ \\
Kepraktisan tenaga kependidikan & $92,5 \%$ \\
\hline
\end{tabular}

Berdasarkan hasil pada Tabel 3. dapat diketahui untuk mengukur kepraktisan kepala sekolah mendapatkan persentase 94,8\%, kepraktisan guru mendapatkan presentase 87,6\%, dan kepraktisan tenaga kependidikan mendapatkan presentase 92,5\%, yang artinya kepala sekolah, guru, dan tenaga kependidikan dapat dengan mudah menggunakan Preventive E-Education berbasis aplikasi Play Store. Berdasarkan keterangan kriteria analisis kepraktisan, dengan demikian Preventive E-Education berbasis aplikasi Play Store dinyatakan "Sangat Praktis". Sejalan dengan penelitian terdahulu yang dilakukan (Hartono, 2015) dengan judul "Pengembangan monopoli Pembelajaran Matematika Berbasis Permainan Monopoli Indonesia" menunjukkan bahwa hasil tes pada tahap pratindakan, siswa yang tuntas belajar sebanyak 36,7\%, sedangkan pada siklus I sebanyak 60\%, dan pada siklus II sebanyak 83,3\%.

Penilaian terhadap hasil edukasi untuk guru. Hasil edukasi guru dapat dinyatakan tuntas apabila Kadar Hb memenuhi kadar yang normal yaitu di bawah 150 miligram per desiliter (mg/dl) sesuai dengan ketentuan yang diberikan oleh Kementrian Kesehatan RI dan nilai challenge dan quiz melebihi $80 \%$. Presentase nilai rata-rata keseluruhan hasil dari challenge dan quiz guru setelah melakukan edukasi preventif menggunakan Preventive E-Education berbasis aplikasi Play Store adalah 95\%. Dengan demikian guru mampu membatasi dependensi pada asupan gula, garam, dan lemak berlebih menggunakan Preventive E-Education berbasis aplikasi Play Store dengan nilai melebihi KKM challenge dan quiz dan pengembangan Preventive E-Education berbasis aplikasi Play Store dapat dikatakan berhasil. Berdasarkan hasil penilaian tersebut tingkat keefektifan yang diperoleh dikategorikan "sangat efektif". Sejalan dengan peneliti terdahulu yang di lakukan (Hartono, 2015) dengan judul "Pengembangan monopoli Pembelajaran Matematika Berbasis Permainan Monopoli Indonesia" menunjukkan bahwa hasil tes pada tahap pratindakan, siswa yang tuntas belajar sebanyak $36,7 \%$, sedangkan pada siklus I sebanyak $60 \%$, dan pada siklus II sebanyak 83,3\%.

Lembar validasi yang digunakan menggunakan skala likert dengan kriteria penilaian diantaranya:

Tabel 4. Skala Likert

\begin{tabular}{cc}
\hline Presentase (\%) & Kriteria Kualitatif \\
\hline $80 \%-100 \%$ & Sangat Baik \\
$66 \%-79 \%$ & Baik \\
$56 \%-65 \%$ & Cukup Baik \\
$0 \%-55 \%$ & Kurang Baik \\
\hline
\end{tabular}

(Arikunto, 2009:245)

Dari beberapa validasi dan uji coba yang telah dilakukan, dapat disimpulkan bahwa edukasi kesehatan berbasis aplikasi Play Store yang dikembangkan telah memenuhi kriteria valid, praktis, dan efektif yang dapat digunakan dalam pembelajaran. Hal ini didukung dengan pendapat (Sabil, 2012) yang menyatakan bahwa kualitas perangkat pembelajaran yang baik dapat dilihat dari kriteria kevalidan (validity) dan kepraktisan (practically).

Pengembangan Preventive E-Education berbasis aplikasi Play Store ini berpotensi memberikan inovasi dan edukasi baru dalam membatasi dependensi pada asupan gula, garam, dan lemak sehingga presentase kesehatan masyarakat Indonesia khususnya pada anak-anak usia sekolah dasar di kota Malang meningkat dan jumlah penderita penyakit Diabetes Mellitus akibat kelebihan konsumsi gula, garam, dan lemak menurun serta dapat menambah wawasan guru di sekolah dasar melalui program UKS untuk mengembangkan edukasi kesehatan yang relevan sesuai perkembangan teknologi di era revolusi industri 4.0 .

\section{KESIMPULAN}

Preventive E-Education berbasis aplikasi Play Store merupakan produk media yang telah dikembangkan berdasarkan langkah-langkah model penelitian pengembangan ADDIE dengan menggunakan 5 tahapan yaitu Analyze (Analisis) yang meliputi: analisis kurikulum, analisis kebutuhan, 
dan analisis karakteristik kepala sekolah, guru, dan tenaga kependidikan, Design (Desain) yang meliputi: perancangan bahan pembuatan media dan instrumen penelitian, Development (Pengembangan) yang meliputi: pengembangan Preventive E-Education berbasis aplikasi Play Store dan validasi, Implementation (Implementasi) yang meliputi: uji coba produk pada kepala sekolah dan 50 guru kelas di SD negeri dan swastas se-gugus 4 Kecamatan Blimbing Kota Malang, dan Evaluate (Evaluasi) yaitu pengevaluasian setiap tahapan untuk mengetahui ketercapaian pengembangan Preventive E-Education berbasis aplikasi Play Store. Pada tahap evaluate (evaluasi) tidak dilakukan oleh peneliti karena keterbatasan waktu. Media Preventive E-Education berbasis aplikasi Play Store untuk membatasi dependensi pada asupan gula, garam, dan lemak. Disini peneliti lebih fokus pada edukasi preventif untuk membatasi dependensi pada asupan gula, garam, dan lemak berlebih. Preventive E-Education berbasis aplikasi Play Store dikategorikan layak digunakan sebagai Preventive E-Education berbasis aplikasi Play Store untuk membatasi dependensi pada asupan gula, garam, dan lemak berlebih.

\section{DAFTAR PUSTAKA}

Abdul, Gafur. 2012. Desain Pembelajaran. Yogyakarta: Ombak.

Abdurahman, Riswaya. 2014. Aplikasi Pinjaman Pembayaran Secara Kredit Pada Bank Yudha Bhakti. Jurnal Computech dan Bisnis.

Amir, A., Lesmana, O., \& Negeri, K. D. (2018). PENINGKATAN PERAN USAHA KESEHATAN SEKOLAH (UKS) TINGKAT SEKOLAH DASAR SE-KECAMATAN TELANAIPURA KOTA JAMBI.

Amir, M. T. 2013. Inovasi Pendidikan Melalui Problem Based Learning : Bagaimana Pendidik Memberdayakan Pemelajar di Era Pengetahuan. Jakarta : Kencana

Anwari, M., Vidyawati, R., Salamah, R., Refani, M., Winingsih, N., Yoga, D., ... Susanto, T. (2018). Pengaruh Senam Anti Hipertensi Lansia Terhadap Penurunan Tekanan Darah Lansia Di Desa Kemuningsari Lor Kecamatan Panti Kabupaten Jember. The Indonesian Journal of Health Science, (September), 160. https://doi.org/10.32528/ijhs.v0i0.1541

Aoun, J.E. 2017. Robot-proof: higher education in the age of artificial intelligence. US: MIT Press.

Arifin, Z. 2012. Evaluasi Pembelajaran. Bandung: PT Remaja Rosda Karya.

Arikunto, S., 2009. Prosedur Penelitian Suatu Pendekatan Praktik. Edisi Revisi 6. Jakarta : Rineka Cipta.

Arikunto Suharsimi. 2010. Manajemen Penelitian. Jakarta: Nusantara Semarang.

Arikunto, Suharsimi. 2013. Prosedur Penelitian : Suatu Pendekatan Praktik. Jakarta: Rineka Cipta.

Arizal, H., Januarsa, A., \& Fadhila, E. (2018). Perancangan Motion Graphic Dalam Membatasi Konsumsi Gula, Garam Dan Lemak Bagi Dewasa Muda. Jurnal Rekamana Institut Teknologi Nasional, 1-15.

Ayu, F. (2009). Pengembangan Media Pendidikan Untuk Inovasi Pembelajaran. 1(2), 2-6.

Balan, Y. A. (2017). Pengembangan Model Computer-Based Test (CBT) Berbasis Adobe Flash untuk Sekolah Menengah Kejuruan. Innovative Journal of Curriculum and Educational Technology, 6(1), 36-44.

Esther Oduntan, O., Adepoju Adeyanju, I., Olatunde Olabiyisi, S., \& Olusayo Omidiora, E. (2015). Evaluation of N-gram Text Representations for Automated Essay-Type Grading Systems. International Journal of Applied Information Systems, 9(4), 25-31. https://doi.org/10.5120/ijais15-451394

Hartono, S. R. (2015). PEMBELAJARAN MATEMATIKA BERBASIS PERMAINAN. 2.

Hidayah, L., Nurazizah, Y., \& Rahmawati, I. (2019). Pengembangan media edukasi kesehatan berbasis ebook. Seminar Nasional Teknologi Dan Informatika, 57-62.

Kirna, I. M. (2012). PENGEMBANGAN BAHAN AJAR METODE PENELITIAN PENDIDIKAN DENGAN ADDIE 


\section{MODEL. 2.}

Kreano, J. (2012). Desain Model Pengembangan Perangkat Pembelajaran Matematika. Kreano: Jurnal Matematika Kreatif-Inovatif, 3(1), 59-72. https://doi.org/10.15294/kreano.v3i1.2613

Masturah. (2018). PADA MATA PELAJARAN IPA KELAS III SEKOLAH DASAR Setiap warga negara Indonesia. $9,215-225$.

As'ari, A. R. (2014). Mengupayakan Pembelajaran Yang Sesuai Tuntutan Kurikulum 2013. Seminar Pendidikan, (September 2014). https://doi.org/10.13140/2.1.1389.2644.

Balan, Y. A. (2017). Pengembangan Model Computer-Based Test (CBT) Berbasis Adobe Flash untuk Sekolah Menengah Kejuruan. Innovative Journal of Curriculum and Educational Technology, 6(1), 36-44.

Blogger, B., Mtsn, D. I., \& Jember, A. (n.d.). Pengembangan Media Pembelajaran Matematika Berbasis Web Menggunakan. 2(2), 145-155.

Esther Oduntan, O., Adepoju Adeyanju, I., Olatunde Olabiyisi, S., \& Olusayo Omidiora, E. (2015). Evaluation of N-gram Text Representations for Automated Essay-Type Grading Systems. International Journal of Applied Information Systems, 9(4), 25-31. https://doi.org/10.5120/ijais15-451394.

Kirna, I. M. (2012). PENGEMBANGAN BAHAN AJAR METODE PENELITIAN PENDIDIKAN DENGAN ADDIE MODEL. 2.

Kistianita, A. N., \& Gayatri, R. W. (2015). ANALISIS FAKTOR RISIKO DIABETES MELLITUS TIPE 2 PADA USIA PRODUKTIF DENGAN PENDEKATAN WHO STEPWISE STEP 1 (CORE / INTI) DI PUSKESMAS. 1.

Kreano, J. (2012). Desain Model Pengembangan Perangkat Pembelajaran Matematika. Kreano: Jurnal Matematika Kreatif-Inovatif, 3(1), 59-72. https://doi.org/10.15294/kreano.v3i1.2613.

Masturah. (2018). PADA MATA PELAJARAN IPA KELAS III SEKOLAH DASAR Setiap warga negara Indonesia. $9,215-225$.

Mustaji. (2013). Pengembangan Bahan Ajar Dengan Model ADDIE Untuk Mata Pelajaran Matematika Kelas 5 SD. 1, 1-15.

Nugroho, K. U. Z., Darmi, Y., \& Soneta, A. (2017). Pengaruh Penerapan E-Evaluation Dalam Pembelajaran Terhadap Kinerja Guru Matematika Sma Kota Bengkulu. None, 2(2), 151-154.

Oktaviara, R. A., \& Pahlevi, T. (2019). Pengembangan E-modul Berbantuan Kvisoft Flipbook Maker Berbasis Pendekatan Saintifik pada Materi Menerapkan Pengoperasian Aplikasi Pengolah Kata Kelas X OTKP 3 SMKN 2 Blitar. Jurnal Pendidikan Administrasi Perkantoran, 7(3), 61.

Pringsewu, S. M. A. N. (2018). Jurnal Informasi dan Komputer Volume 6 Nomor 12018 Jurnal Informasi dan Komputer Volume 6 Nomor 1 2018. 6, 20-30.

Prodi, M., Sains, P., Universitas, P., \& Surabaya, N. (2013). PENGARUH E-EVALUATION BERSIKLUS TERHADAP. 3(1), 299-305.

Purnama, I. (2017). PENGEMBANGAN PERMAINAN MONOPOLI SEBAGAI MEDIA PEMBELAJARAN INTERAKTIF BERBASIS PENDEKATAN SAINTIFIK PADA MATERI EKOSISTEM UNTUK SISWA KELAS X SMA OLEH. 1-8.

Racma, D. F. (2015). DENGAN METODE PENGACAKAN BANK SOAL PADA MATERI JARINGAN KOMPUTER 1 MENGGUNAKAN. 4(4), 14-23.

Rahman, B. (2014). PENGEMBANGAN MEDIA PEMBELAJARAN INTERAKTIF ANIMASI FLASH PADA STANDAR KOMPETENSI MEMASANG INSTALASI PENERANGAN LISTRIK BANGUNAN SEDERHANA DI SMK WALISONGO 2 GEMPOL Subuh Isnur Haryudo. (1). 
Rhomdani, R. W. (2017). Pengembangan Media Pembelajaran Matematika Berbasis Web Menggunakan Blogmath (Bligger \& Mathjax). Matematika Dan Pendidikan Matematika, 2(2), 145-155.

Sabil, S. dan H. (2012). Edumatica Volume 02 Nomor 02, Oktober 2012. 02, 57-67.

Sadikin, A., \& Hakim, N. (2019). Biodik : Jurnal Ilmiah Pendidikan Biologi Interactive Media Development of E-Learning in Welcoming 4.0 Industrial Revolution On Ecosystem Material for High School Students Pengembangan Media E-Learning Interaktif Dalam Menyongsong Revolusi Industri 4 . . 5(2), 131138.

Studi, P., Pembelajaran, T., \& Pascasarjana, P. (2012). I Made Candiasa Program Studi Teknologi Pembelajaran Program Pascasarjana Undiksha.

Widoyoko, E. P. (2012). Teknik Penyusunan Instrumen Penelitian. Yogyakarta: Pustaka Pelajar, 15, 22.

Widyastuti, M., Studi, P., \& Bahasa, P. (2018). PENGGUNAAN MEDIA ELEKTRONIK HOT POTATOES PADA. 5(3), 213-218.

Yasa, A. D. (2018). Pengembangan Modul Tematik Berbasis STM (SAINS, TEKNOLOGI DAN MASYARAKAT). 6(April), 21-26. 